\title{
Autoimmune chronic active hepatitis in a family
}

\author{
S Hodges, A Lobo-Yeo, P Donaldson, M S Tanner, D Vergani
}

\begin{abstract}
A positive family history of autoimmune disease is common among patients with autoimmune chronic active hepatitis, but usually autoimmunity is directed at organs other than the liver. We document for the first time the multiple occurrence of autoimmune chronic active hepatitis in a family. Out of a sibship of seven, three sisters developed this, one sister developed coeliac and autoimmune thyroid disease, one sister showed serological signs of autoimmunity, while the two brothers were well with no signs of autoimmunity. HLA typing showed that in association with the female sex DR3 seems to be more important than B8 in conferring susceptibility to autoimmune chronic active hepatitis, at least in this family.
\end{abstract}

The concept that a form of chronic active hepatitis has an autoimmune pathogenesis stems from the following observations. Patients with this condition have raised concentrations of circulating immunoglobulins, in particular IgG; an increased titre of non-organ specific autoantibodies including smooth muscle, nuclear, and liver/kidney microsomal autoantibodies ${ }^{12}$; raised concentrations of activated $\mathrm{T}$ lymphocytes in the circulation ${ }^{3}$; and a dense mononuclear cell infiltrate in their portal tracts. ${ }^{4} \mathrm{~A}$ defect in number and function of $\mathrm{T}$ suppressor cells is also typically found in patients $s^{5}$ and some healthy first degree relatives. ${ }^{6}$ Relatives may also have high titres of circulating autoantibodies. ${ }^{7}$

Genetic predisposition to autoimmune chronic active hepatitis is believed to be conferred by the HLA haplotype B8/DR $3 .{ }^{8}$ Family studies have shown that relatives of patients with this disease have an increased incidence of other autoimmune diseases such as fibrosing alveolitis and coeliac disease. ${ }^{10}$ There is no reported convincing evidence of autoimmune chronic active hepatitis clustering in families. One report described a family in which five members had a chronic liver disease and associated immunological abnormalities presenting over two generations. " No information was given, however, regarding the presence of diagnostic autoantibodies, thus questioning the diagnosis of chronic active hepatitis. A second paper reported cases of chronic liver disease in family members of 11 of 27 children with juvenile cirrhosis, though immunological aspects were not investigated. ${ }^{12}$

We describe a family in whom autoimmune chronic active hepatitis is documented in three of seven siblings. A further sibling has coeliac disease and thyrotoxicosis. This family provided the opportunity to investigate the immunological abnormalities characteristic of chronic active hepatitis in both affected and unaffected family members and to study their segregation with specific HLA allotypes.

Since hepatic copper concentrations may be raised in this disease ${ }^{13}$ it is important to exclude Wilson's disease from the differential diagnosis. This had been done with ${ }^{6+} \mathrm{Cu}$ studies.

\section{Subjects}

The family is of Indian origin; all the children were born in the United Kingdom and the parents are non-consanguineous.

The proband (II-7) (Fig 1) presented at the age of 11 years with a one month history of central abdominal pain, pale stools, and jaundice. The liver was palpable $4 \mathrm{~cm}$, and the spleen $3 \mathrm{~cm}$, below the costal margin. Ascites was absent. Results of the investigations were as follows: serum bilirubin concentration $165 \mu \mathrm{mol} / \mathrm{l}$; conjugated bilirubin $145 \mu \mathrm{mol} / \mathrm{l}$ (normal $<17 \mu \mathrm{mol} / \mathrm{l}$ ); alanine aminotransferase activity 1392 IU/l (normal 5-30 IU/l); $\gamma$-glutamyltransferase $30 \mathrm{IU} / 1$ (normal 4-18 IU/l); alkaline phosphatase 285 IU/l (normal 21-100 IU/l); alpha $\hat{1}^{-}$ antitrypsin phenotype was $M M$; hepatitis B surface antigen was negative, smooth muscle antibody and antimitochondrial antibody were positive in a titre of 1 in 256; IgG was raised $(50.9 \mathrm{~g} / \mathrm{l}$; normal 6-16 g/l). A liver biopsy specimen showed features of active cirrhosis with nodules of variable size separated by fibrous septa. There was active piecemeal necrosis and rosettes of hepatocytes were present. Parenchymal cholestasis was evident. She was treated initially with prednisolone $(10 \mathrm{mg} /$ daily $)$ and azathioprine (50 mg daily). After nine months treatment was changed to penicillamine because of excessive weight gain. This was discontinued four months later because of heavy proteinuria and the prednisolone and azathioprine restarted. A second liver biopsy specimen two years later showed a normal lobular architecture without piecemeal necrosis. Macronodular cirrhosis was not excluded. She remains symptomless at the age of 19 but continues to require daily prednisolone $(10 \mathrm{mg})$ and azathioprine ( $50 \mathrm{mg}$ ).

A sister of the proband (II-2) (Fig 1) had died at another hospital at the age of 9 years from liver disease. Her notes were reviewed. She had presented with a two month history of vomiting and abdominal distension and a three week history of pale stools and dark urine. Initial physical examination had shown jaundice, clubbing, palmar erythema, and hirsutism. Her liver was enlarged $3 \mathrm{~cm}$ below the costal margin. Liver biopsy was not performed because of abnormal clotting but investigations suggested autoimmune chronic active hepatitis. She had conjugated hyperbilirubinaemia with a serum bilirubin concentration of $130 \mu \mathrm{mol} / \mathrm{l}$, alanine amino transferase and alkaline phosphatase were 


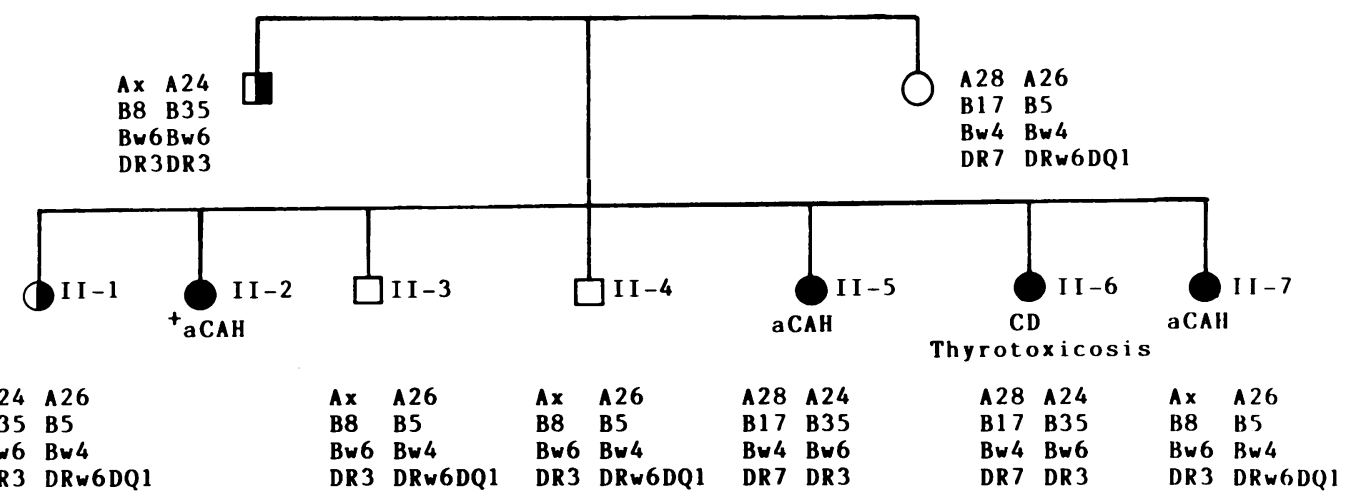

Figure 1: Family pedigree. Filled symbols represent patients with autoimmune disease; half filled symbols represent autoantibody positive subjects without evidence of disease. HLA haplotypes are listed by each subject. aCAH=autoimmune chronic active hepatitis; $C D=$ coeliac disease $++=$ died.

raised at $578 \mathrm{IU} / 1$ and $392 \mathrm{IU} / 1$ respectively. Antinuclear antibody and smooth muscle antibody were positive at a titre of 1 in 800 . She had macrocytic anaemia (haemoglobin $0.6 \mathrm{~g} / \mathrm{l}$; mean cell volume 116). Serum copper concentration was at the upper limit of normal but there was no excess copper in the urine, and no increase in 24 hour urinary copper excretion after penicillamine. Screening for hepatitis B was negative. She was treated with prednisolone, but one month later developed liver failure and died. No necropsy was permitted.

A second sister has coeliac disease and thyrotoxicosis (II-6) (Fig 1). She presented at the age of 5 with iron deficiency anaemia and pale bulky stools. A jejunal biopsy specimen showed subtotal villus atrophy and there was an excellent response to gluten withdrawal. Thyrotoxicosis was diagnosed at age 16 when she was noted to have warm, moist hands, a collapsing pulse, sinus tachycardia, and a palpable thyroid gland. Thyroxine and triiodothyronine concentrations were raised and thyroid secreting hormone oversuppressed $(309 \mathrm{nmol} / 1,7.5 \mathrm{nmol} / 1,<0.05 \mathrm{mIU} / 1$ respectively). Thyroglobulin and thyroid microsomal antibodies were positive at a titre of 1 in 6400. Antinuclear and smooth muscle antibodies were negative. Transaminases have always been in the normal range. The thyrotoxicosis has been successfully treated with carbimazole.

The remaining members of the family were screened for abnormal liver function at the time of the proband's diagnosis. A 13 year old sister (II-5) was asymptomatic but had high alanine aminotransferase activity (700 IU/l). Smooth

TABLE I Results of immunological investigations

\begin{tabular}{|c|c|c|c|c|c|c|c|}
\hline $\begin{array}{l}\text { Family } \\
\text { member }\end{array}$ & Sex & Diagnosis & Autoantibodies & $\operatorname{Ig} G$ & $\operatorname{Ig} A$ & $\operatorname{Ig} M$ & $\begin{array}{l}\% \text { DR positive } \\
\text { T lymphocytes }\end{array}$ \\
\hline Father & & Well & $\begin{array}{l}\text { ANA } 1 / 40 \\
\text { SMA } 1 / 40\end{array}$ & $17 \cdot 5$ & $1 \cdot 2$ & $1 \cdot 2$ & $12 \cdot 6$ \\
\hline Mother & & Well & Negative & $19 \cdot 3$ & $5 \cdot 2$ & $1 \cdot 1$ & $4 \cdot 1$ \\
\hline & $\begin{array}{l}\mathrm{F} \\
\mathrm{F}\end{array}$ & $\begin{array}{l}\text { Well } \\
\text { aCAH (died) }\end{array}$ & ANA $1 / 40$ & $14 \cdot 0$ & $2 \cdot 2$ & 0.9 & $4 \cdot 1$ \\
\hline II-3 & $M$ & Well & Negative & $15 \cdot 3$ & $4 \cdot 6$ & $1 \cdot 1$ & $5 \cdot 6$ \\
\hline $\begin{array}{l}\mathrm{II}-4 \\
\mathrm{II}-5\end{array}$ & $\begin{array}{l}M \\
F\end{array}$ & $\begin{array}{l}\text { Well } \\
\text { aCAH }\end{array}$ & $\begin{array}{l}\text { Negative } \\
\text { SMA } / 40\end{array}$ & $\begin{array}{l}15 \cdot 2 \\
16 \cdot 7\end{array}$ & $\begin{array}{l}4 \cdot 2 \\
2 \cdot 0\end{array}$ & $1 \cdot 0$ & $\begin{array}{r}5 \cdot 2 \\
10 \cdot 4\end{array}$ \\
\hline II-6 & $\mathrm{F}$ & $\begin{array}{l}\text { aCAH } \\
\text { CD/aTD }\end{array}$ & $\begin{array}{l}\text { SMA } 1 / 40 \\
\text { ANA } 1 / 40\end{array}$ & $\begin{array}{l}16 \cdot 1 \\
16 \cdot 1\end{array}$ & $\begin{array}{l}2 \cdot 0 \\
2 \cdot 8\end{array}$ & $\begin{array}{l}2 \cdot 1 \\
0 \cdot 7\end{array}$ & $\begin{array}{r}10 \cdot 4 \\
7 \cdot 4\end{array}$ \\
\hline $\begin{array}{l}\text { II }-7 \\
\text { Proband }\end{array}$ & $\mathrm{F}$ & $\mathrm{aCAH}$ & SMA $1 / 320$ & $21 \cdot 5$ & $1 \cdot 4$ & $1 \cdot 5$ & $6 \cdot 8$ \\
\hline
\end{tabular}

Normal values: Autoantibodies: negative; IgG 5-16 g/l; IgA 0.5-4.5 g/l; IgM 0.5-2.0 g/l; DR positive T lymphocytes $<6 \%$.

ANA = antinuclear antibody; SMA = antismooth muscle antibody; $\mathrm{aCAH}=$ autoimmune chronic active hepatitis; $\mathrm{CD}=$ coeliac disease; $\mathrm{T} \mathrm{T}=$ autoimmune thyroid disease. muscle antibody was positive 1 in 16 . A liver biopsy specimen showed piecemeal necrosis and lymphocytic infiltration in the portal tracts. She was initially treated with prednisolone but, as was done for her sister, treatment was changed to penicillamine; she too developed heavy proteinuria and after six months was put back to prednisolone. A deep vein thrombosis occurred at the age of 18. At 20 she had normal transaminases and discontinued prednisolone, but rising transaminases two years later required restarting steroid treatment.

The other members of the family remain healthy without clinical or biochemical evidence of chronic liver disease.

\section{Methods}

Identification of activation markers (HLA-DR) on $T$ cells. HLA-DR positive T lymphocytes were identified using a technique described in detail previously. ${ }^{3}$ Briefly, $T$ lymphocytes were purified by rosetting with neuraminidase treated sheep red blood cells and HLA-DR was detected using HLA-DR phycoerythrin conjugated monoclonal antibody (Becton-Dickinson) in direct immunofluorescence.

Non-organ specific autoantibodies. Non-organ specific autoantibodies were detected by indirect immunofluorescence technique using rat liver, kidney, and stomach as substrate. ${ }^{14}$

Hepatitis $B$ markers. HBsAg, anti-HBc, $\mathrm{HBeAg}$, and anti-HBe were measured by radioimmunoassay (Ausria, Corab, Abbot).

HLA typing. HLA typing was performed by microcytotoxic assay modified from Terasaki et al..$^{15}$

Copper studies. Serum, urinary (before and after $20 \mathrm{mg} / \mathrm{kg}$ of penicillamine), and hepatic copper measurements were performed by atomic absorption spectrometry and caeruloplasmin by radial immunodiffusion in the propositus and sibling II-5. ${ }^{64} \mathrm{Cu}$ studies were performed in the father, all siblings, and in a 3 year old child with Wilson's disease. $11 \cdot 1 \mathrm{MBq}{ }^{64} \mathrm{Cu}$ in $2 \mathrm{mg}$ of cupric sulphate was administered in $150-200 \mathrm{ml}$ of milk after an eight hour fast. ${ }^{16}$ Blood samples were collected at $2,4,18,28$, and 42 hours in heparin. Radioactivity was counted on $4 \mathrm{ml}$ of whole plasma. Incorporaton of ${ }^{6+} \mathrm{Cu}$ into caeruloplasmin was carried out by ammonium sulphate precipitation of globulins and counting 
TABLE II Results of copper studies on two surviving patients with autoimmune chronic active hepatitis

\begin{tabular}{|c|c|c|}
\hline Patient & II-5 & II-7 \\
\hline $\begin{array}{l}\text { Serum caeruloplasmin }(\mathrm{g} / \mathrm{l}) \\
\quad(\text { normal range }>180 \mathrm{~g} / \mathrm{l})\end{array}$ & 330 & 144 \\
\hline $\begin{array}{l}\text { Urine } \mathrm{Cu}(\mu \mathrm{g} / 24 \mathrm{~h}) \\
\text { Before D-penicillamine }\end{array}$ & $21 \cdot 6$ & $22 \cdot 6$ \\
\hline $\begin{array}{l}\text { After D-penicillamine } \\
(20 \mathrm{mg} / \mathrm{kg}) \\
(\text { normal range }<500)\end{array}$ & 1311 & 1068 \\
\hline $\begin{array}{l}\text { Liver Cu }(\mu \mathrm{g} / \mathrm{g} \text { dry weight) } \\
\text { (normal range 15-55) } \\
\text { (Wilson's }>250 \text { ) }\end{array}$ & $\begin{array}{l}\text { Pretreatment } \\
123 \\
\text { After } 2 \text { years' } \\
\text { treatment } \\
74.5\end{array}$ & $\begin{array}{l}\text { Pretreatment } \\
388 \\
\text { After } 2 \text { years' } \\
\text { treatment } \\
102\end{array}$ \\
\hline
\end{tabular}

radioactivity in both supernatant (albumin) and globulin precipitate (caeruloplasmin). ${ }^{17}$ The rapid decay of ${ }^{64} \mathrm{Cu}(\mathrm{t} 1 / 2=12.8$ hours $)$ necessitated careful timing of samples and corrections of counts with simultaneous standards.

\section{Results}

Immunological studies. There were increased numbers of activated $\mathrm{T}$ lymphocytes or raised levels of autoantibodies or both in the three surviving sisters with autoimmune disease, in their healthy sister and father, but not in the two brothers or mother. Moderately raised concentrations of IgG were seen in the three affected siblings and mother and father (Table I).

HLA studies. Figure 1 shows the family pedigree and HLA haplotypes. The father has the haplotype HLA-B8 DR3, being heterozygous for B8 and homozygous for DR3. All the children possess DR3 but only some B8. HLA-B8 was found in one of the two sisters with chronic active hepatitis and in both healthy brothers. DR7 was found in the sister with coeliac disease and thyrotoxicosis.

Copper studies. One of the two sisters with chronic active hepatitis (II-7) had a low serum caeruloplasmin. Both sisters had normal 24 hour urinary copper excretion after penicillamine. Both sisters had raised liver copper concentrations, in one (II-7) over $250 \mu \mathrm{g} / \mathrm{g}$ dry weight. In both the hepatic copper concentration fell after two years' treatment (Table II). The appearance of ${ }^{64} \mathrm{Cu}$ in plasma after administration showed a



Figure 2: Proportion of the ingested dose of ${ }^{*} \mathrm{Cu}$ in the globulin fraction from $1 \mathrm{ml}$ of plasma. The shaded area represents the results of the five healthy family members, mean (SD). The two sisters with aCAH showed supranormal ${ }^{\star} \mathrm{Cu}$ incorporation (II-5, II-7), suggesting increased

caeruloplasmin synthesis as part of the acute phase response. A

3 year old child with Wilson's disease showed no ${ }^{*} \mathrm{Cu}$ incorporation into caeruloplasmin. time course similar to that in control subjects (data not shown). Incorporation of ${ }^{64} \mathrm{Cu}$ into caeruloplasmin was significantly higher in the two sisters with chronic active hepatitis than in the healthy family members, indicating an increased rate of caeruloplasmin synthesis (Fig 2).

\section{Discussion}

This study documents the multiple occurrence of autoimmune chronic active hepatitis in one family and shows that in this family the allotype DR3 but not B8 and the female sex were associated with the occurrence of the disease. Moreover, it shows that immunological changes characteristic of the disease, such as positive autoantibodies and raised numbers of activated $T$ lymphocytes can be present in the first degree relatives who have no evidence of disease.

Two previous studies have described the familial occurrence of a chronic liver disease with features compatible with autoimmune chronic active hepatitis. ${ }^{112}$ Seropositivity for the relevant autoantibodies was not investigated in the first study and was present in only two of five affected family members in the second, which raises questions about the nature of the liver disease. The findings of our study, on the other hand, provide persuasive evidence that this disease can occur in families, since all the affected members were diagnosed according to internationally accepted criteria.

It is widely believed that genetic predisposition to autoimmune chronic active hepatitis is conferred by the possession of specific antigens in the HLA region. The disease was originally reported to be associated with HLA-B $8^{18}$ and subsequently with HLA-DR3. ${ }^{8}$ This dual association is not surprising since the two allelles are in linkage disequilibrium and tend to segregate 'en bloc.' The possession of the haplotype HLA-B8/DR3 is considered to impart a general predisposition to autoimmunity since it is found in a variety of autoimmune disorders. ${ }^{19}$ Whether either allele alone or the B8/DR3 haplotype confer susceptibility to autoimmune chronic active hepatitis is, however, unknown. In the family we have investigated the father had on one chromosome the B8/DR3 haplotype, on the other DR3 in isolation; one of the surviving affected sisters inherited B8/DR3, the other DR3 alone. Thus, the evidence gathered through this family suggests that the allele DR3 is more important than $\mathrm{B} 8$ in conferring susceptibility to aCAH.

Even in this unique family possessing the predisposing HLA genes was not sufficient to convert susceptibility into disease. The two DR3 positive brothers and the DR3 homozygous father had no clinical or biochemical evidence of liver disease. In addition, the two brothers had no signs of altered immunity, the concentrations of immunoglobulin and activated $T$ lymphocytes being normal and autoantibodies being absent. In contrast, altered immunity, including positivity for antinuclear antibody and raised activated $\mathrm{T}$ lymphocytes, was observed in the unaffected sister, showing the dominant role of female sex in the development of autoimmunity. This is further confirmed by the fact that the last 
sister suffers from thyrotoxicosis and coeliac disease.

It is clear from this and previous studies that some of the characteristic immunological alterations of autoimmune chronic active hepatitis can be present in genetically predisposed subjects who do not have the disease ${ }^{67}$ It is possible that alterations of the immune system merely reflect the possession of 'autoimmune' alleles such as DR3, as was the case in the unaffected sister with altered immunity. It has been shown that HLAB8/DR3 positive people tend to have defects of immunoregulation which lead to an overactive immune system. ${ }^{20}$ Alternatively, it is possible that the alterations observed presage the disease, the development of which requires the additive effects of a number of factors to achieve a critical threshold, surmounted which the disease appears. In our family this question will be clarified with time.

The occurrence of liver disease in three siblings with documented raised hepatic copper concentration and raised copper urinary excretion after penicillamine in two raises the possibility of Wilson's disease. This could be unequivocally excluded in the family we investigated for the following reasons. Firstly, raised storage of copper can be present in autoimmune chronic active hepatitis, ${ }^{13}$ while autoantibody positivity is rare in Wilson's disease. Secondly, a fall in hepatic copper was observed with treatment in the two affected surviving sisters. The hepatic copper concentration falls with treatment in autoimmune chronic hepatitis but remains unchanged in Wilson's disease. Thirdly, the incorporation of ${ }^{64} \mathrm{Cu}$ is typically reduced in patients with Wilson's disease, while it was supranormal in the two sisters with chronic active hepatitis.

We describe for the first time the familial occurrence of autoimmune chronic active hepatitis. The study of such a family confirms the dominant role of female sex in imparting susceptibility to autoimmune disease, shows the possible occurrence of autoimmunity in the absence of clinical manifestations, and indicates that within the HLA region the allotype DR3 is more likely to confer susceptibility to the disease than B8.

1 Mackay IR, Wood TY. Lupoid hepatitis: a comparison of 22 cases with other types of autoimmune disease. $Q \mathcal{F} \mathrm{Med}$ 1962; 31: 485-507.

2 Odièvre M, Maggiore G, Homberg JC, et al. Seroimmunologic classification of chronic hepatitis in 57 children. Hepatolog 1983; 3: 407-9.

3 Lobo-Yeo A, Alviggi L, Meili-Vergani G, et al. Preferential activation of helper/inducer $T$ lymphocytes in autoimmun

4 Scheuer PJ. Chronic hepatitis: a problem for the pathologist. Histopathology 1977; 1: 1-5.

5 Kakumu S, Kazuaki Y, Kashio T. Immunoregulatory T cell function in acute and chronic liver disease. Gastroenterology 1980; 79: 613-9.

6 Nouri-Aria KT, Donaldson PT, Hegarty JE, et al. HLA A1-B8-DR3 and suppressor cell function in first degree relatives of patients with autoimmune chronic active hepatitis. F Hepatol 1985; 1: 235-41.

7 Galbraith RM, Smith M, Mackenzie RM, et al. High prevalence of seroimmunolgic abnormalities in relatives of patients with active chronic hepatitis or primary biliary cirrhosis. NEngl F Med 1974; 290: 63-9.

8 Mackay IR, Tait BD. HLA association with autoimmune chronic active hepatitis - identification of the B8 DRw3 chronic active hepatitis - Identification of the B8 DRw3
haplotype by family studies. Gastroenterology 1980; 79: 95-8

9 Williams AJ, Marsh J, Stableforth DE. Cryptogenic fibrosing alveolitis, chronic active hepatitis and autoimmune haemolytic anaemia in the same patient. Br $\mathcal{F}$ Dis Chest 1985; 79. 200-3.

10 Swarbrick ET, Fairclough PD, Campbell PJ, et al. Coeliac disease, chronic active hepatitis and mesangiocapillary glomerulonepritis in the same patient. Lancet 1980; ii 1084-5.

11 Joske RA, Lawrence MB. Familial cirrhosis with autoimmune features and raised immunoglobulin levels. Gastroenterology 1970; 59: 546-52.

12 Ruggieri BA, Baggenstoss AH, Logan GB. Juvenile cirrhosis. $\mathcal{J}$ Dis Child 1957; 94: 64-76.

13 La Russo NF, Summerskill WHJ, McCall JT. Abnormalities of chemical tests for copper metabolism in chronic active liver disease: differentiation from Wilson's disease. Gastroliver disease: differentiation
enterology 1976; 70: 653-5.

14 Johnson GD, Holborow EJ, Dorling J. Immunofluorescence and immunoenzyme techniques. In: Weir DM, ed. Hand book of experimental immunology. Vol 1. Oxford: Blackwell 1978: 15.1-15.30.

15 Terasaki P, McClelland JD, Park MS, et al. Microdroplet lymphocyte cytotoxicity test. In: Manual of tissue typing techniques. Washington DC; US Government Printing Office, 1973: 54-61. (DHEW Publication (NIH) 74-545.)

16 Sternlieb I, Scheinberg IH. The role of radio copper in the diagnosis of Wilson's disease. Gastroenterology 1979; 77 $138-42$.

17 Smallwood RA, McIlveen B, Rosenoer VM, et al. Copper kinetics in liver disease. Gut 1971; 12: 139-44.

18 Mackay IR, Morris PJ. Association of autoimmune active chronic hepatitis with HLA A1-B8. Lancet 1972; ii: 793-5.

19 Bodmer WF. The HLA system and disease. $\mathcal{F} R$ Coll Physicians Lond 1980; 14: 43-50.
Podmer WF. The HLA system

20 Krawitt EL, Kilby AE, Albertini RJ. Immunogenetic studies of autoimmune chronic active hepatitis: HLA, immunoglobulin allotypes and autoantibodies. Hepatology 1987; 7 1305-10. 